\title{
Defunding the ramparts and institutional theory: The master's tools will fell the master's house
}

\author{
Michael J. DeValve*
}

\begin{abstract}
Witnessing current events in Ferguson, and now in Milwaukee, New York, Los Angeles, Seattle, of course Portland, and now Kenosha, Wisconsin, where protests against police violence are met with yet more police violence, the question naturally arises: Why are police so seemingly insistent on actively working counter to their own organizational best interest? This essay poses this troubling question and derives part of an answer for it from institutional theory.
\end{abstract}

\section{INTRODUCTION}

Apart from its wretchedness and that it was viewed by millions worldwide, the fallout from George Floyd's murder was not rooted solely in that murderous moment itself. With Dickensian irony, police have greeted protests against police force with increased brutality. One might conclude the police were seeking to validate the protesters' argument; the police could not do worse for themselves. The failure of policing in this moment, though, is not a failure authored solely by policing.

The more coherent and reasoned portions of the movement to defund the police seek to redirect taxpayer resources to institutions and away from police agencies. The reasoning that gets us to the point of radically reducing police budgets is nothing new. In fact, the idea of shifting responsibilities from the police is a thing for which the police themselves have advocated (e.g., Dennis, Berman, \& Izadi, 2016; Kirkman, 1974). In what is perhaps the most skilled and most germane argument for defunding, Vitale (2017) concludes his scathing and insightful critique of American police by saying that although pervasive training and police-cultural changes are necessary, no technocratic solution for police is possible, because any changes would be resisted at all levels. Post-Floyd reforms like the threatened radical cuts to police budgets in Seattle, Washington, for example, not only ignore the deeper and more frightening issues, the threatened budget cuts themselves did not actually land. Not only was the political will to grapple with the real problems of policing not ever present, the scapegoat agency was brought back into the fold with little more than a scolding.

Criminal justice has been the dumping ground for the grotesque consequences of abandoned co-responsibility; justice agencies are left to clean up messes made by greed, racism, and privilege. Defunding the police should be a thing for which police earnestly pray; defunding is (or should be understood to be), in policing terms, back-up. This essay examines a single question: Why do police organizations flail against what is so evidently in their own organizational best interest in the current crisis of legitimacy? This question is akin to the question that inspired institutional theory (Meyer \& Rowan, 1977; DiMaggio \& Powell, 1983), so institutional theory is a natural source for insights. The companion question, to wit, what can be done to bring the institution of policing into a place where its members are able to serve with love's wisdom at the helm, is the focus of the commentary essay that accompanies this work in this volume.

\section{Institutional Theory}

Institutional theory has had considerable influence on the discourse on organizations (e.g., Chandler \& Hwang, 2015; Fredriksson, 2014; Hiss, 2009; Maier \& Simsa, 2020; Suddaby, 2014). If we assume that organizations operate rationally towards particular ends, given the wide range of ends they might pursue and the settings in which they might pursue them, it is reasonable to assume that organizations' structures and operations would vary, determined by conditions and desired outcomes. It turns out, however, that organizations look and act much alike. This unexpected homogeneity is the point of departure for institutional theory (DiMaggio \& Powell, 1983; Meyer \& Rowan, 1977). In the shadow of the demise of principles of administration (e.g., Simon, 1946), mid-century organizational theorists sought to understand the forces that compelled organizations into unexpected symmetry.

A further concern haunted mid-century organizational theorists: if indeed efficiency is the driving force behind how and why organizations organize and act, it seems altogether

Correspondence to: Michael J. DeValve, PhD, Assistant Professor, Department of Criminal Justice, Bridgewater State University, Bridgewater, MA O2325, USA. E-mail: mdevalve@bridgew.edu

To cite: DeValve, M. J. (2020). Defunding the ramparts and institutional theory: The master's tools will fell the master's house. Journal of Community Safety and Well-Being, 5(4), 138-143. https://doi.org/10.35502/jcswb.160

@ Author(s) 2020. Open Access. This work is distributed under the Creative Commons BY-NC-ND license. For commercial re-use, please contact sales@sgpublishing.ca. gg PUBLISHING Published by SG Publishing Inc. OSA Official publication of the Community Safety Knowledge Alliance. 
odd that organizations are made in a way that seems almost counter to the optimization of efficiency. Instead of rational, goal-directed, efficiency-optimized principles guiding them like Polaris, something else was at work making organizations, and making them do what they do. Meyer and Rowan (1977) concluded that a set of values, ideas, and expectations extant in the wider community, and in particular among professional communities, worked to weave themselves into organizational culture and structure, and that these values, ideas, and expectations (which Meyer and Rowan call "myths"), once institutionalized, became the driving force of organizational structure and action. These myths worked to create homogeneity, something institutional theorists call isomorphism. Many of these myths ended up operating with the force of law or policy, while others were more normative. The internalized myths make the organization legitimate in the eyes of others.

Institutional theory hangs on the seeming tension between expectations regarding formal structure and linelevel operation. Under the influence of myths, organizations decouple: a semi-intentional cleavage forms between formal structure and line-level activity. This decoupling buffers formal structure and organizational leadership from critique. A gap arises between stated and actual organizational outcomes; what is formally stated as its purpose and aim is not necessarily what the organization actually does, resulting in a disjointedness evident in assessments of activity. Decoupling allows organizations to "get things done" at the ground level that are "necessary," if occluded and distasteful, while shielding leadership from critique for failing to meet stated goals. The reasoning of "good faith," a kind of trust default setting, completes the picture, ultimately contributing to organizational legitimacy. Legitimacy is the key: the myths that end up being institutionalized operate in pervasive ways on organizations, but specifically to garner legitimacy for the organization in the eyes of its constituent communities. But legitimate-ness-ness, rather than legitimacy itself, becomes the overriding concern. Because they are built and operate according to environmental forces more than the force of rationality toward efficiency, organizations tend to look not only like each other but also like the forces in the environment that shape them; because they actually prize legitimacy more than success regarding stated goals, organizations tend to do things that make little practical, goal-related sense but instead serve the aim of cultivating their own legitimacy.

DiMaggio and Powell paraphrase Schelling (1978, p. 14): "organizations in a structured field respond to an environment that consists of other organizations responding to their environment, which consists of organizations responding to an environment of organizations' responses" (emphasis added). The layered and churlish topography of environments works on organizations from many directions at once; as other organizations navigate their own paths through their own fields, the wake they issue becomes treacherous seas or still water for other organizations elsewhere (1983, p. 149).

DiMaggio and Powell (1983) offer a three-part typology for understanding environmental influences towards isomorphism. Coercive pressures are driven by the need for legitimacy, and by the consequences for not achieving it (e.g., the loss of accreditation). Mimetic pressures arise from the uncertainty which organizations confront when charged with complex and multivalent tasks; organizations often borrow what is thought to work elsewhere to help them navigate uncertainty. Normative pressures arise from shared meanings and expectations of actors with influence in the organization's environment (e.g., professionals). Coercive, mimetic, and normative forces towards isomorphism not only urge towards homogenization, however; institutional forces can be as differentiating as they are homogenizing (Beckert, 2010).

\section{Institutional Theory and the Institution of Policing}

Institutional theory is a natural choice for examining policing (e.g., Crank, 2003; Crank \& Langworthy, 1992), but the ready applicability of institutional theory to policing does not mean that it is capable of guiding critique. Questions have been raised about the capacity of institutional theory to sustain meaningful critique regarding power relations (e.g., Suddaby, 2014; Willmott, 2015).

Still, institutional theory would posit that, in an effort to achieve legitimacy in response to challenges regarding brutality, police would be less, not more, likely to use violence. Instead, nonviolent protests have been met with outsized, even cruel force, and the shooting of unarmed Black Americans continues, seemingly unabated.

I argue that the cleaved and cratered topography of the policing environment, marked by deep decoupling in justice practice generally, the charged field of multivalent demands on police, and the enhancement of extant myths related to the purpose of police and the nature of justice have all resulted in the enemization of citizens and the fortification of organizational boundaries that have in turn resulted in violent conflicts wholly inconsistent with the continuation of the American police institution as such.

Individual and systemic racism is powerfully and undeniably at work creating our current low state. But it is the failures of the institution that have revealed the ugly (i.e., racist) realities of policing, "good faith" being all but fully evaporated as the organizational cloister has become embattled (see, e.g., Janis, 1972).

Perhaps the clearest example of institutional isomorphism in policing is patrol. As we have understood for decades (see, e.g., Kelling, 1981; Kelling, Pate, Dieckman, \& Brown, 1974; Crank \& Langworthy, 1992), patrol is only moderately effective for interdicting crime, and yet it remains the largest, indeed defining, policing endeavour. Patrol is so central to legitimacy that a police chief is unlikely to be effective without having spent time doing patrol herself.

Evidence supports the notion that police adopt policies supported by only equivocal evidence. Consistent with DiMaggio and Powell (1983), Burruss and Giblin (2014) found centrist forces (including professionalized forces and other police agencies) to have an influence on the adoption of community policing programming.

\section{The Myth Minefield}

Claims on police from the environment are not unidirectional, predictable, or within organizational control to influence or coopt (e.g., Beckert, 2010), and this multivalence is an essential component in the historic failure revealed in the present moment's calamities.

\section{Police Have Anticriminogenic Efficacy}

Police activity, we know now, is only rather weakly and locally related to changes in the presence of street crime in 
communities (e.g., Andresen \& Malleson, 2014; Andresen \& Shen, 2019; Novak, Fox, Carr, \& Spade, 2016; Uchida \& Swatt, 2013) and hardly related at all to crimes that do vast harm (i.e., corporate, government, and state crime). Said another way, working with all they have currently, police can make us only marginally safer. Crucially, they pose a clear and present danger to the well-being of significant portions of the human community. What makes people and communities safe has relatively little to do with enforcement activities and far more to do with tracing and transforming suffering in its myriad forms.

\section{Cornerstone Coercion}

At the very heart of what it means to be a police officer is the capacity to use force. Police have a monopoly with regard to the use of state force (e.g., Crank, 2015), and this monopoly sets the police apart from most any other organization in the compass of human activity. The coercion-as-cornerstone myth has at least four sub-themes: militarization, war-on-crime symbology, the problem-solving efficacy of force, and that Job One is to get home at the end of one's shift.

Militarization as Manifestly Logical for Police. The militarization of police (e.g., Kraska, 2001; Kraska \& Cubellis, 1997 ) is the continuation of a theme present at the founding of policing. The first of Peel's nine principles of policing (likely authored by Rowan and Mayne, the first commissioners of the Metropolitan Police (Home Office, 2012)) states that the alternative to the prevention of crime and disorder is a resort to "military force and the severity of legal punishment." We can do this the easy way, or we can do it the hard way.

Because force has become the defining attribute of American policing, organizational components from the military (e.g., rank) are thought to be essential for police organizations. As DiMaggio and Powell (1983) observe, organizations often look to other successful organizations for ideas regarding how to structure themselves in contexts of uncertainty and volatility. Quasi-military organizational components were adopted early on in the history of policing (e.g., Monkkonen, 1992, p. 549); if the new police were to be force-empowered, a forced-based organizational metaphor would help create legitimacy for it.

War on Crime. The war analogy for confronting crime has a long, brutal history (e.g., Shelden \& Vasiliev, 2018). Perhaps the war analogy is merely rhetorical and seeks to invite reference to the totality of effort implied by a state of war. However, the analogy enemizes members of the community and fortifies the ramparts of the righteous (DeValve, 2017), encouraging a blurring of jus ad bellum (justification for war) and jus in bello (right conduct in war). If it is defensible to wage war against crime, then there should be few checks on the means of the conduct of that war.

Force Solves Problems. Force does not solve problems. It creates them. Force is necessary at times, but defining police in terms of the force monopoly means that force frames and interpenetrates all police action. Given the broad and vastly complex police mandate (Brodeur, 2007), understanding police in terms of the capacity to use force is like understanding astrophysics solely in terms of the finding and tracking of extinction-capable near-earth asteroids.

Job One: Get Home. Common fodder in police academies and locker rooms is the idea that, at the end of all contemplation, the most important measure of success for police is that each officer goes home at the end of her shift. Survival is Job One, all other concerns are subsidiary. This idea runs diametrically opposed to the principle of public service; were this idea to have any validity, necessarily it would leach from policing any iota of nobility.

\section{Policing the Community Legitimately}

For some, the myth of a community, something between a Norman Rockwell painting and John Cougar Mellencamp ditty, operates behind the idea of community policing (e.g., Crank, 2015). An ideal community, rooted in traditional values, is theorized, and policing, if attuned to those values, can be more impactful (really, for it being legitimate). This assumption is as flawed as it is seductive.

From the very beginning of the policing institution, its chief founder and architect recognized the central role of legitimacy in the success of the institutional endeavour. Without legitimacy of the institution, policing in a democracy is doomed to failure. Several of Peel's principles pay homage to the importance of the consent of the policed, and that consent is in turn a function of legitimacy. Of course, the only way to achieve true trustful legitimacy is not to seek it as such, but merely to be legitimate, to be trustworthy.

In this crisis of legitimacy for police, it makes perfect sense that representatives of embattled police agencies would engage in what seems like victim-blaming because it is legitimate-ness-ness they seek, not authentic trust as such. Recently we learned (e.g., Yancey-Bragg et al., 2020) that Jacob Blake had a knife in his car. Chief Miskins of the Kenosha Police Department intimated that the people killed by Kyle Rittenhouse were at fault for their own demise (Stahl, 2020) because they were out after curfew. It is far preferable for innocent civilians to take blame than for the police to be delegitimized for their inaction or incapacity. Let the bodies hit the floor.

\section{Enemization}

Useful for the creation of a community rooted in identity and constructed values is the manufacture of out-groups. Boundaries become a key mechanism from an institutional perspective, and for boundaries to be meaningful, enemies are needed. Communities of Color are both purposefully chosen and conveniently available for enemization (e.g., Durr, 2015, Williams, 2015; Williams, 2019). The long, continued and unspeakably sickening history of the enemization of Black and Brown peoples by government agencies need not be repeated here; no treatment in this space could hope to do justice to it.

\section{Bad Apples}

One tendency is to view instances like the murder of Michael Brown, Philando Castile, Walter Scott, and others as an instance of a poor police officer doing a bad job, and that no indictments can be lodged against the police. "Bad-appleing" officers who murder unarmed citizens is yet another effort, 
if dimly understood by those who use it, to shore up fading organizational legitimacy.

\section{Organizational Command Presence}

The idea of the continuum of force has fallen out of favour, and for good reasons, but there is a component to the continuum of force that is rarely mentioned. Officer presence, the first level in the now-defunct but still somehow influential continuum of force, is the idea of a command presence. Strong voice and authoritative body posture are the first cultivated tactics to ensure compliance. Organizations have a command presence, too, but it takes the form of staid and solid timelessness of the organizations themselves. I am fond of observing that policing as an institution is 70 years younger than the Guinness beer factory in Dublin; this observation is intended to challenge directly the cultivated organizational command presence.

\section{Deep Decoupling}

A deep divide exists between stated goals and actual practice in policing. Elsewhere (DeValve, 2015), I speak about the abyssal divide between mechanisms of crime causation and the things we do to confront crime; I refer to this divide as the etiology-action divorce. Decoupling in policing, real as it is with regard to mission, action, and evaluation, is only a special case of the divide between stated purposes and streetlevel activity. I refer to this divide here as "deep decoupling" because the divide is so deep it splits the field entirely, even cleaving us from ourselves.

The deep decoupling can be seen at work with regard to current evaluative and accountability practices (e.g., COMPSTAT) and the simultaneously authoritative and disappointing content of best-practices repositories like www.crimesolutions.gov. It is at least as present in academic criminology. Weisburd and Piquero (2008) demonstrate the tenuous and diminishing predictive power of increasingly sophisticated quantitative criminological research (notably, even as they continue to produce it). Young (2011) then rails against the disingenuous, ineffective, and curiously hubristic body of quantitative positivistic criminology, still without meaningful rejoinder.

\section{MYTHS ABOUT JUSTICE}

\section{Consensus and the Law}

The power of law is rooted in the assumption that it is agreed upon by a significant portion of the community. The consensus assumption of law is a special case of the social contract. After the demise of the king sovereign, the Enlightenmentera idea of the social contract was the first attempt at a post-monarchical social order creation myth, and it did the office tolerably well at the time. Today, however, the idea of a contract is a clumsy and inapt analogy for human gravity. We socialize, we organize into human communities not through some ceding of a portion of our sovereign hegemony to a Leviathan, but through and because of love (e.g., DeValve, 2015).

Yet another concern here is the idea of the criminal as a discrete human phenomenon. The implication of the law being a result of consensus is that there is some discernible corpus of humanity committed to non-consensus activities. Whether that non-consensus activity is driven by ecological factors, differential social organization, drift, life on the corner, the dysfunctional American Dream, low self-control, or some other tired and half-baked notion, crime is not a discrete phenomenon that exists as an exogenous phenomenon outside of humans. It is, simply put, pain caused by pain.

\section{Justice is Fairness}

Justice, it is thought, is a result of fairness. According to this school of thought, comparative calculi with regard to justice inputs (i.e., harm) and outputs (i.e., punishment) yields a precise form of justice onto which everyone can affix their approval. As a particular instance of fairness, arguably derivable from Rawls's (1971) ideas, procedural justice (e.g., Tyler, 2012) is thought to be essential to the justice project. Although procedural justice is necessary, it is hardly sufficient (e.g., DeValve, Garland, \& Wright, 2018). Framing social justice in terms of procedural justice only misleads. Process is vital for justice but only in the same way hygiene is vital for surgery. Without care, a focus on procedural justice alone coronates and reifies the traditional hegemonic (i.e., oppressive) order by reaffirming extant (and oppressive) ideas and relationships.

\section{Concluding Thoughts on Myths}

The many competing and colliding myths, some mentioned here and some unvoiced, are a function of co-created discourses that permeate and surround the police institution. These myths are perpetuated according to the degree to which they resonate with individuals. What resonates, of course, is a function of the topography of need in each of us and in terms of the wider human community, and it is for this reason that we do well to contemplate together the topographies of that need in the wider human community and the ways we can organize to address them.

The range of guiding myths for policing is not only bedecked with false and misleading ideas, it is deeply valanced in at least two wildly different vectors. On the one hand, there is a vector that urges a wisdom, a softening of the shape of boundary-spanning contacts (e.g., DeValve \& Quinn, 2010). This vector is not nearly as prolific or as influential as the second one, which urges a honing of the edge (e.g., Crank, 2015) through militarization, not only of equipment, but of personnel and of the very spirit of the agency (e.g., Kraska, 2001).

\section{COERCION, MIMESIS, AND THE NORMATIVE AT WORK IN POLICING}

The typology offered by DiMaggio and Powell (1983) serves us well in an attempt to understand the forces that act on police, moving them away from serving their (and our) wiser interests. As Beckert (2010) observed, environmental forces impel both convergence towards isomorphism and divergence from connection with the wider field of public service.

\section{Coercive Forces}

Organizations operate uncertainly in a field of other organizations operating uncertainly in response to uncertain operations of organizations. Constant and complex interaction is daily fare for criminal justice agencies; a deep interconnectedness is at work throughout the criminal justice organizational archipelago. Influences, both formal and 
informal, at executive, mid-management and street levels, work in grand and tiny ways on organizations in the system.

Police officers today understand Peel's insight that legitimacy is everything, but the means to achieve it seem occluded from view. Considerable pressure arises from the field to identify and use "best practices." Borrowing Einsteinian wisdom, agencies are incentivized to take what is measurable to be the things that matter, and to relegate things that really matter but are nearly impossible to measure to special departments, or to ignore them altogether. As a result, "legitimate-ness-ness" becomes the coin of the realm and actual legitimacy, true authentic service is deemphasized. Thus, coercive forces towards isomorphism not only disincentivize rational, outcome-efficient strategies, they also make it exceedingly easy not to care in the least for non-cops or their needs.

\section{Mimetic Forces}

Contemplating retirement, a personal friend and police executive lamented, after a long and distinguished career marked by leadership and first-class heroism, that after all he had done the community seemed no better. Haberman (2016) documented a tragic, almost ritualistic sense of capacity among police executives despite evidence that the techniques they used were anemic. The sense of efficacy, as out-of-round as it is, is also perfectly natural. It is rooted in mimetic forces that act on police. There is often no clear sense of achievement, mostly because the sense of mission is contrived almost from whole cloth. There are pleasant myths related to protecting and serving, but hardly can we say that these myths make any sense in large segments of the human community (e.g., Barlow \& Barlow, 2018; Durr, 2015).

The reality of policing in America is akin to a floor drain in a truck stop bathroom: a little intervention from a hose and all of the bad choices that occur there end up in the center of the room. The difference, though, is that no one blames the drain for its filth. As a society, we abandon each other whenever doing so is easy or profitable; the end result is that an already wildly complex task of squaring off against a Gordian Knot of suffering falls to the police, and for this task we have equipped them with none of the necessary tools for the job. Of course they use force when police do not know what else to do. As we have seen, it is the only real tool at their disposal. Indeed, it is the tool that defines them as police. We should be surprised when police succeed at confronting human suffering and don't tune someone up.

The sense of being unappreciated for the impossible job with which they have been tasked works wonders to deepen an already considerable divide between the police and the policed. That the police actually are the community matters not at all; either through reckless disregard or active disdain, the community has abdicated its responsibility to itself, and the police are stuck with the cheque.

\section{Normative Forces}

In other areas of human activity, professionalization creates a structuring influence on organizational activity. In policing, the professionalization movement has diminished police officer discretion, and sought to prioritize goal-directed activities through the cultivation of a knowledge base (see, e.g., Crank, 2015; Joplin \& Marwah, 2013). Thus, police professionalization has contributed to the isolation and militarization of police against the communities they serve. Academic criminal justice has contributed to this isolation and militarization through a focus on studies concerned with maximizing effectiveness and efficiency of action.

\section{CONCLUSION}

The current low state of policing in America, specifically the tendency of police agencies to operate counter to their own best interests (that is, counter to the interests of the communities they purport to serve) is one condensate of the deep decoupling that has arisen from the pursuit of legitimate-nessness over authentic trust. This legitimacy shell-game, though, is driven in no small measure by the many and competing claims made upon policing by the wider communities in their environment. The commentary companion to this essay will address in greater detail how we might prevent and repair the rot revealed in places like Ferguson, Missouri, Minneapolis, Minnesota, and Kenosha, Wisconsin.

\section{CONFLICT OF INTEREST DISCLOSURES}

The author has no conflicts of interest to declare.

\section{AUTHOR AFFILIATIONS}

* Department of Criminal Justice, Bridgewater State University, Bridgewater, MA, USA.

\section{REFERENCES}

Andresen, M., \& Malleson, N. (2014). Police foot patrol and crime displacement: A local analysis. Journal of Contemporary Criminal Justice, 30(2), 186-199.

Andresen, M., \& Shen, L. (2019). The spatial effect of police foot patrol on crime patterns: A local analysis. International Journal of Offender Therapy and Comparative Criminology, 63(8), 1446-1464.

Barlow, D., \& Barlow, M. (2018). Police in a multicultural society: An American story, 2nd ed. Long Grove, IL: Waveland.

Beckert, J. (2010). Institutional isomorphism revisited: Convergence and divergence in organizational change. Sociological Theory, 28(2), $150-166$

Brodeur, J. (2007). An encounter with Egon Bittner. Crime Law \& Social Change, 48, 105-132.

Burruss, G., \& Giblin, M. (2014). Modeling isomorphism on policing innovation: The role of institutional pressures in adopting communityoriented policing. Crime \& Delinquency, 60(3), 331-355.

Chandler, D., \& Hwang, H. (2015). Learning from learning theory: A model of organization adoption strategies at the microfoundations of institutional theory. Journal of Management, 41151, 1446-1476.

Crank, J. (2003). Institutional theory of police: A review of the state of the art. Policing: An International Journal of Police Strategies \& Management, 26(2), 186-207.

Crank, J. (2015). Understanding police culture, 2nd ed. New York: Routledge.

Crank, J., \& Langworthy, R. (1992). An institutional perspective of policing. Journal of Criminal Law and Criminology, 83(2), 338-363.

DeValve, M. (2015). A different justice: Love and the future of criminal justice practice in America. Durham, NC: Carolina Academic Press.

DeValve, M. (2017). O for a muse of fire: Rebellion as sacrament. Critical Criminology, 25, 87-102.

DeValve, M., Garland, T., \& Wright, B. (2018). A unified theory of justice and crime: Justice that love gives. Lanham, MD: Lexington/Rowman \& Littlefield. 
DeValve, M., \& Quinn, E. (2010). Practical poetry: Thich Nhat Hanh and the cultivation of the problem-oriented officer. Contemporary Justice Review 13, 2, 191-205.

Dennis, B., Berman, M., Izadi, E. (2016, July 11). Dallas police chief says "we're asking cops to do too much in this country." Washington Post. Retrieved from: https://www.washingtonpost.com/news/ post-nation/wp/2016/07/11/grief-and-anger-continue-after-dallasattacks-and-police-shootings-as-debate-rages-over-policing/

DiMaggio, P. J., \& Powell, W. W. (1983). The iron cage revisited: Institutional isomorphism and collective rationality in organizational fields. American Sociological Review, 48(2), 147-160.

Durr, M. (2015). What is the difference between slave patrols and modern day policing? Institutional violence in a community of color. Critical Sociology 41, 6, 873-879.

Fredriksson, M. (2014). Crisis communication as institutional maintenance. Public Relations Inquiry, 3(3), 319-340.

Haberman, C. (2016). A view inside the "black box" of hotspot policing from a sample of police commanders. Police Quarterly, 19(4), 488-517.

Hiss, S. (2009). From implicit to explicit corporate responsibility: Institutional change as a fight for myths. Business Education Quarterly, 19(3), 433-451.

Home Office. (2012, December 10). Definition of policing by consent. UK Home Office. https://www.gov.uk/government/publications/ policing-by-consent/definition-of-policing-by-consent

Janis, I. (1972). Victims of groupthink. New York: Houghton Mifflin.

Joplin, J., \& Marwah, S. (2013). Democratizing police professionalization and division of labor. Journal of the Institute of Justice and International Studies 13, 115-129.

Kelling, G. (1981). Conclusion. The Newark Foot Patrol Experiment (pp. 111-129). Washington, DC: The Police Foundation.

Kelling, G., Pate, T., Dieckman, D., \& Brown, C. (1974). The Kansas City preventive patrol experiment: A summary report. Washington, DC: The Police Foundation.

Kirkman, G. (1974, March). A professor's "street lessons." FBI Law Enforcement Bulletin (pp. 14-17).

Kraska, P. (2001). Militarizing the American criminal justice system: The changing roles of armed forces and police. Boston: Northeastern University Press.

Kraska, P., \& Cubellis, L. (1997). Militarizing Mayberry and beyond: Making sense of American paramilitary policing. Justice Quarterly, 14|41, 607-629.
Maier, F., \& Simsa, R. (2020, May). How actors move from primary agency to institutional agency: A conceptual framework and empirical application. Organization. doi:10.1177/1350508420910574.

Meyer, J. W., \& Rowan, B. (1977). Institutionalized organizations: Formal structure as myth and ceremony. American Journal of Sociology, 83(2), 330-363.

Monkkonen, E. (1992). History of urban police. Crime and Justice 15, 547-580.

Novak, K., Fox, A., Carr, C., \& Spade, D. (2016). The efficacy of foot patrol in violent places. Journal of Quantitative Criminology, 12, 465-475.

Rawls, J. (1971). A theory of justice. Belknap.

Schelling, T. (1978). Micromotives and macrobehavior. W. W. Norton.

Shelden, R., \& Vasiliev, P. (2018). Controlling the dangerous classes: A history of criminal justice in America, 3rd ed. Waveland.

Simon, H. (1946). The proverbs of administration. Public Administration Review, 6(1), 53-67.

Stahl, J. (2020, August 26). Kenosha police chief blames protesters for their own deaths, defends vigilante groups. Slate. https://slate.com/ news-and-politics/2020/08/kenosha-police-chief-daniel-miskinisblames-protesters-for-own-deaths.htm

Suddaby, R. (2014). Can institutional theory be critical? Journal of Management Inquiry, 24(1), 93-95.

Tyler, T. (2012). Justice and effective cooperation. Social Justice Research, $25,355-375$.

Uchida, C., \& Swatt, M. (2013). Operation LASER and the effectiveness of hotspot patrols: A panel analysis. Police Quarterly, 16(3), 287-304.

Vitale, A. (2017). The end of policing. New York: Verso.

Weisburd, D., \& Piquero, A. (2008). How well do criminologists explain crime? Statistical modeling in published studies. Crime \& Justice, 37, 453-502.

Williams, J. (2019). Race as carceral terrain: Black lives matter meets reentry. Prison Journal, 99(4), 387-395.

Williams, K. (2015). Our enemies in blue: Police and power in America. Oakland, CA: AK Press.

Willmott, H. (2015). Why institutional theory cannot be critical. Journal of Management Inquiry, 24(1), 105-111.

Yancey-Bragg, N., Marley, P., Volpenhein, S., Shannon, J., \& Culver, J. (2020, August 26). Kenosha shooting: One officer fired seven shots into Jacob Blake's back; teen arrested in killing of protesters. USA Today. https://www.usatoday.com/story/news/ nation/2020/08/26/kenosha-protests-jacob-blake-what-weknow/3441684001/

Young, J. (2011). The criminological imagination. Malden, MA: Polity Press. 